\title{
Accelerated Development in sub-Saharan Africa: an Agenda for Structural Adjustment Lending?
}

\author{
Philip Daniel
}

\section{Introduction}

Accelerated Development in sub-Saharan Africa: an Agenda for Action [World Bank 1981a] provides the first comprehensive example of the new post McNamara ${ }^{1}$ World Bank thinking applied to a whole region rather than an individual country. If the Report is representative, concern for reduction of inequalities, provision for basic needs, and alleviation of absolute poverty appears to have fallen in the Bank's ranking of priorities. Equity and distribution concerns have been supplanted by a re-emphasis upon the growth of production, and upon the adoption of 'outwardoriented' policies as a means of adjustment in the face of structural balance of payments problems. This policy change has coincided with the expansion of general balance of payments lending by the Bank, in support of approved 'structural adjustment' programmes. The Accelerated Development Report is the strongest general statement to date of the policy change. It is also the most detailed public exposition of the kinds of programmes the Bank would be willing to support with structural adjustment lending.

While this evolution in World Bank thinking has been rapid and recent, the International Monetary Fund has been moving towards a complementary position over a longer period. Since the introduction of the Extended Fund Facility (EFF) in 1974 (with three years for disbursements and up to 10 years for repayments) the Fund has steadily increased the volume of resources devoted to longer term 'stabilisation' or 'adjustment' programmes, and has broadened the scope of these programmes to couple the traditional emphasis on demand restraint with policies directed toward easing supply constraints. These policies normally consist of trade and payments

\footnotetext{
${ }^{1}$ Accelerated Development was in fact drafted during President McNamara's administration. However, its tone and priorities are distinctly different from those of his crusade against absolute poverty.

2In the last three years, the Fund has substantially increased its total volume of lending, and has also sharply raised the proportion of new lending which is extended on terms of full conditionality. In Africa attempted programmes reached record levels during 1980-81, but disbursements have lagged because of a high rate of programme suspension.
}

liberalisation and removal of price 'distortions', rather than measures of structural or institutional reform. ${ }^{2}$ Since the Bank tends to give structural adjustment loans to countries that have previously arranged programmes with the Fund, ${ }^{3}$ there is now considerable international pressure on deficit countries to adopt not only short-term fiscal and monetary policies but also longer-term development strategies approved by the Bank and the Fund.

The Report also calls for remarkably sweeping changes in practices of bilateral donors. There is some difference between what is implied throughout the Report, and what is made explicit in the recommendations on aid contained in the final chapter. Nevertheless the main thrust is clear: while total aid should be increased, bilateral donors should scale down aid for development projects and contribute instead to support for Bank-designed structural adjustment programmes. It is the combination of proposals for national policy reform with proposals for re-direction of aid which endow the Report with potential to have a tremendous impact - especially, but not only, on African countries.

\section{The Domestic Policy Diagnosis}

After an opening discussion of the serious effects on African economies of international economic developments in the 1970s; of the continuing obstacles to development inherited as part of the colonial legacy; and of climatic and other geographical difficulties faced in sub-Saharan Africa (SSA), the Report concentrates upon three critical 'domestic policy inadequacies' which it considers have impeded economic growth:

first, trade and exchange rate policies have overprotected industry, held back agriculture, and absorbed much administrative capacity. Second, too little attention has been paid to administrative constraints in mobilising and managing resources for development; given the widespread weakness of

${ }^{3} \mathrm{~A}$ Fund EFF Programme does not, however, guarantee a Bank structural adjustment loan, as became clear in Tanzania in 1980 .

Bulletin, 1983, vol 14 no I, Institute of Development Studies, Sussex 
planning, decision-making, and management capacities, public sectors frequently become overextended. Third, there has been consistent bias against agriculture in price, tax and exchange rate policies.

[World Bank 1981a:4]

In looking at the implications of the Report for aid flows and practices, it is worth pausing to consider the origins of these three arguments.

The first is an adaptation of the World Bank's welltaken criticism of 'inward-orientation' in trade and exchange rate policies (summarised in World Bank [1981b:63-78]). This is derived from an assessment of the comparative growth and adjustment experiences of a number of middle-income, semi-industrial countries during the $1970 \mathrm{~s}$. The argument, in brief, runs as follows. Those countries which have adopted liberal trade regimes (ie, without significant quantitative restrictions); low and uniform import tariff structures; and measures to ensure that their real effective exchange rates have depreciated against those of their trading partners, are described as 'outward-oriented'. They have adjusted more rapidly, with smaller losses of real income, than other groups of countries. The central feature of "outwardorientation' is that the structure of incentives should not discriminate between production for export and production for the home market. 'Inward-orientation', on the other hand, involves a high degree of protection for import-substituting industries (whether by tariff or quantitative restrictions); discriminatory taxation of export production; and an appreciating real effective exchange rate. 'Outward-oriented' policies have enabled those countries which adopt them to overcome a structural balance of payments deficit by producing more goods for export. 'Inward-oriented' policies inhibit this form of adjustment, and therefore throw the burden onto deflation and slower growth. The Report argues that most African countries have pursued 'inward-oriented' policies for far too long.

Three points should be made about this analysis. First, the basic research following which the relative merits of 'inward' and 'outward' orientation have been assessed related mainly, though not exclusively, to semi-industrial, middle income countries outside SSA, in particular the 'newly-industrialising countries' or NICs [see, for example, the work of Balassa 1981, 1982 and Krueger 1978]. The Report's application of these conclusions to Africa is derivative and is based upon internal work conducted at the World Bank. [Apart from the Report itself, the main published examples are Acharya and Johnston 1978, and Liebenthal 1981.]

Second, the NICs have economies in which both the short and long run price-elasticity of supply of traded goods (ie exportables and importables) can be taken as relatively high, partly because the traded goods produced by the NICs consist of increasing shares of manufactured goods, not primary commodities. To argue that they may be lower in less diversified economies, such as those of SSA, is not the same thing as asserting that African producers exhibit inadequate or perverse supply response. It is rather to argue that the structural constraints upon supply responsiveness (land shortage, climate, access to markets etc) may be greater. In the same vein, it can be argued that the exchange rate will have stronger effects upon relative prices in a more diversified economy than in one in which the structure of relative prices is essentially imported and domestically modified primarily by budgetary measures and changes in real wages. The inward/outward orientation argument revolves around price incentives. There is an implicit assumption in the Report's analysis that relative prices are of equal importance in determining the structure of production in all types of economy, and that trade policy measures and exchange rate variations have similar effects upon relative prices in all countries.

Third, the transition to 'outward-orientation' that is recommended requires measures which coincide with those the International Monetary Fund has consistently urged members to adopt, in particular the abolition of exchange restrictions and quantitative trade controls.

The second 'domestic policy inadequacy' identified by the Report is a tendency to over-extend the public sector. Treatment of this issue in the Report is case specific to SSA, and is based less on economic research and analysis than on generalisation from the observation of political and administrative processes in selected cases and countries. This line of argument is consistent with the preference for liberal trade and payments regimes, and thus once again coincides with the requirements of IMF stabilisation programmes. In marked contrast to the thrust of World Bank policies in the recent past, the Report makes very little mention of the redistributive role of the public sector. Its prescription for the public sector is dealt with in two parts: first, the public sector should be less directly involved in the production of goods and services; second, public administration (especially the administration of economic policy and planning) should be strengthened. The implications for aid flows are considerable. Capital projects administered by public agencies should give way to generalised lending to the private sector through financial institutions, while technical assistance for skill development and 'institution-building' in the public sector should be increased.

The third policy problem, the bias against agriculture, is presented as a result of the other two. It is argued 
that trade and exchange rate policies have - by protection - raised the cost of agricultural inputs, and - by currency overvaluation - reduced the returns to farmers, especially on exports and secondarily on import competing foods, in terms of domestic currency. Further, the Report observes that administered prices, taxation and the operations of public sector marketing authorities have diverted resources away from agriculture. The logic of the argument is that, for agriculture to prosper, a switch to 'outward orientation' in trade and exchange rate policy, and dismantling public sector involvement in productive and distributive activities should take precedence over the allocation of more public sector resources to agriculture. Of course, the Report is also arguing for the allocation of an increased portion of (diminished) budgetary resources to agriculture, but not in the form of specific projects administered by government agencies. ${ }^{4}$

The framework for policy reform to promote development in the long term is based upon these three sets of domestic policy issues. African countries' immediate need for short term balance of payments support is seen to be closely related to these policy failures. 'Inward-orientation' has created industries which are not just import-intensive, but require imports to be priced at levels which imply exchange rate over-valuation and low tariffs on imported inputs. These industries thus run into severe difficulties when there is a physical shortage of foreign exchange, or when the domestic prices of imported inputs rise as a result of nominal exchange rate depreciation. The expansion of the public sector has created capital projects in transport, communications, education and health which encounter similar problems of meeting recurrent and maintenance costs in times of foreign exchange scarcity. ${ }^{5}$ In summary, the development patterns of the recent past have increased the demand for foreign exchange, while damaging the capacity to earn it.

\section{Implications for Donors}

The Report's recommendations thus imply both increased aid and policy reform. It explicitly links the two by stressing that additional aid is not only needed for emergency reasons, or to add to available resources in the long term, but to ease the transition to new policies. In other words, it is needed to support structural adjustment. From here it is only a very short

\footnotetext{
${ }^{4}$ While the Report does not specifically say so, this may flow from its observation that policy attention and resource allocations to agriculture by SSA states (and \&onor agencies) grew sharply in the 1970s, while average agricultural output growth rates fell by about a half.

${ }^{5}$ The Report is not fully consistent in respect to these sectors. Its specific citations often call for selective expansion and enhanced maintenance. The proposals for health, education and rural water charges, plus lower primary school teacher salaries, seem unlikely to offset the additional resource allocations apparently recommended.
}

step to the recommendation that the disbursement of additional aid should be made conditional upon the recipient government's adoption of a programme of structural adjustment measures agreed with the donor(s). The practice of conditionality has always been an essential part of members' access to IMF resources. In the Report this is broadened in scope to encompass development assistance flows as well as short term balance of payments support, and longterm development policy as well as short-term demand management measures.

The Agenda for Action confronts bilateral donors (and other multilateral or regional agencies accustomed to disbursing project aid) with a set of radical proposals to reform their current practices:

i) project aid should be scaled down, and replaced by a larger volume of programme aid (both of a sectoral and of a commodity imports kind) and of general balance of payments support;

ii) whatever its form (project or programme), aid should place less emphasis on new capital projects, and more on rehabilitation, maintenance and recurrent cost implications of new activities. Donors should also be willing to support more local and recurrent costs. They are advised to be more 'flexible' about all nonpolicy restrictions on aid disbursement;

iii) accordingly, donors should be much less concerned about monitoring direct government implementation of the projects which they sponsor. Instead they should aim to see that their financial resources are utilised outside the public sector;

iv) donors should be prepared to provide these more flexible forms of support where they are satisfied that the recipient government is pursuing policies conducive to structural adjustment. One way to become satisfied on this point is to support, and allocate funds within the framework of, a structural adjustment programme negotiated and supervised by the World Bank and/or the IMF;

v) the total volume of aid should be greatly increased, total Overseas Development Assistance (ODA) to SSA should nearly double in real terms between 1980 and 1990 .

Apart from their domestic policy implications these proposals accord with long-standing demands from less developed countries not only for more aid, but for greater flexibility in the methods of transfer. Increased flows of foreign exchange freely available for maintenance, rehabilitation and the recurrent costs of development programmes have obvious advantages to SSA countries. It would also be a major step forward 
for embattled African administrations to have to deal with fewer individual donors, fewer differing administrative systems, and fewer foreign-funded projects. Upper Volta, for example, is reputed to deal with almost as many separate donor agency missions as there are days in a year. Under the Report's proposals, international aid would come to resemble more closely other forms of resource transfer (such as commercial lending, or direct investment), and could be more explicitly viewed as a minor redistributive feature of the international economic system.

In all these respects, the proposals of the Report present considerable difficulty for bilateral donors. Their aid administrations are organised around project aid. Thus they can reasonably claim to be ill-equipped to appraise the macro-economic policy and development strategy of a recipient country. The commercial and industrial lobbies of donor countries are likely to view any move away from the foreign exchange financing of new capital projects with great suspicion, even if they have sometimes been prepared to compete for contracts in the absence of procurement tying (as in the aid programmes of West Germany, the Scandinavian countries and, more recently, Japan). Parliamentary accountability in aid budgets may be more difficult to achieve where the closely-monitored project is not the dominant modus operandi. Perhaps most alarming of all is the implication that a greater proportion of aid should become multilateral in character, at least in terms of decisions as to allocation, even if not of formal lending agency. This would be the practical effect of bilateral support for structural adjustment lending organised by the World Bank and the IMF. Amidst all these problems, the bilateral donors face the currently highly unwelcome proposal to increase the volume of aid.

\section{Aid and Conditionality}

The concept of conditionality is now central to the World Bank's efforts to convince donors that there are alternatives to the traditional methods of disbursement. In the face of past failures of recipient government policy and administration the Report argues that the effectiveness and accountability of aid should be safeguarded through alternative means. It rejects the practice of detailed intervention in the processes of public administration, in favour of using the leverage which aid disbursement in large quantities can provide to force recipients to adopt general policy measures. It is implied that these will lessen the scope for governments to misuse aid. The issue of the geographical allocation of a fixed quantity of aid, and of the selection of governments deemed 'aid-worthy', is approached by the same means. The adoption of structural adjustment and development policy pack- ages along the lines proposed in the Report will serve as the criterion for aid-worthiness.

The original purposes of conditionality attached to IMF lending for balance of payments support were to ensure that a member in deficit would repay its debt, and that it would conform to the Fund's articles of agreement. In this sense, conditionality was simply an extension of the covenants commonly included in loan agreements between private lenders and borrowers. Fund conditionality, however, soon came to be made up of policy packages designed to ensure debt repayment and conformity with international exchange and trade relations rules. Given that Fund lending was of short maturity, and designed to deal with shortterm problems, the policy packages which conditionality required were narrowly focused on demand restriction (to bring about the most rapid possible transition to external balance) and on measures to reduce payments restrictions. In large part because the Fund was heavily criticised for this short-term and narrow approach, it moved into longer-term EFF lending in 1974. More recently it has increased its own borrowing to devote more resources to extended programme lending in the current world recession. The Fund has also revised its conditionality guidelines [1979], and begun to stress the importance of 'supply factors' in adjustment. In practice, this has meant an increased Fund interest in public sector operations (eg tax policy and the management of public enterprises) and in measures to remove pricing distortions. [See Daniel 1981 for a fuller discussion.]

The World Bank's adoption of conditionality, and its introduction of structural adjustment lending, are thus complementary to Fund activities, and represent logical extensions of the development of Fund conditionality.

The thrust of the Report's argument is that there is a need for a large-scale shift towards the new structural adjustment type of lending. The final chapter of the Report, however, contains recommendations for donors which are more modest in scope, and are evidently constrained by current practices and interests in aid commitment. The Report makes a plea for an increase in non-project assistance, but acknowledges a need for continued project lending and calls for harmonisation of aid procedures without explicitly asserting that these should be subordinated to Bank-Fund structural adjustment programmes.

In fact the World Bank's own structural adjustment lending programme has so far taken up only a small proportion of total Bank and International Development Association (IDA) resources. By the end of the 1981 fiscal year, the Bank had lent just over US $\$ 1$ bn for structural adjustment. This was equivalent to 
Key components of World Bank structural adjustment operations: February 1, 1980-June 30, 1981

\begin{tabular}{|c|c|c|c|c|c|c|c|c|}
\hline & Senegal & Turkey $^{1}$ & Guyana & Kenya & Bolivia & Philippines & Mauritius & Malawi \\
\hline $\begin{array}{l}\text { Trade policy } \\
\text { Exchange rate policy } \\
\text { Tariff reform and import } \\
\text { liberalization } \\
\text { Export incentives } \\
\text { Improved institutional support } \\
\text { for exporters (export insurance } \\
\text { and financing, export promotion } \\
\text { institutions) } \\
\text { Specific programs for major } \\
\text { export or import saving sectors }\end{array}$ & $\begin{array}{l}x \\
x\end{array}$ & $\mathrm{x}$ & $\mathrm{x}$ & $x$ & $\mathrm{x}$ & $x$ & $\begin{array}{l}\mathrm{x} \\
\mathrm{x}\end{array}$ & $x^{x}$ \\
\hline $\begin{array}{l}\text { Sector policies } \\
\text { Energy: } \\
\text { Pricing policy } \\
\text { Conservation measures } \\
\text { Development of indigenous sources } \\
\text { Agriculture: } \\
\text { Pricing policy } \\
\text { Improved institutional support } \\
\quad \text { (marketing, etc) } \\
\text { Industry: } \\
\text { Incentive system } \\
\text { Institutional improvements and } \\
\text { subsector programs }\end{array}$ & $\mathrm{x}$ & $\begin{array}{l}\mathrm{x} \\
\mathrm{x} \\
\mathrm{x} \\
\mathrm{x} \\
\mathrm{x} \\
\mathrm{x}\end{array}$ & $\begin{array}{l}\mathrm{x} \\
\mathrm{x} \\
\mathrm{x}\end{array}$ & $\mathrm{x}$ & $\mathrm{x}$ & 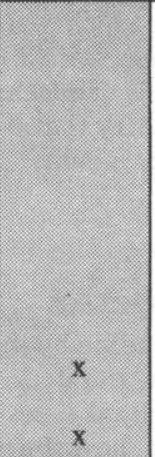 & $\begin{array}{l}\mathrm{x} \\
\mathrm{x} \\
\mathrm{x}\end{array}$ & $\mathrm{x}$ \\
\hline $\begin{array}{l}\text { Public investment program } \\
\text { Revision and review of sectoral } \\
\text { priorities } \\
\text { Strengthening of institutional } \\
\text { capacity to formulate and } \\
\text { implement public investment } \\
\text { program }\end{array}$ & $\mathrm{x}$ & $x$ & $\mathrm{x}$ & $\mathrm{x}$ & $\mathrm{x}$ & & $\mathrm{x}$ & $x$ \\
\hline $\begin{array}{l}\text { Public sector enterprises } \\
\text { Financial performance } \\
\text { Institutional efficiency }\end{array}$ & $\begin{array}{l}x \\
x\end{array}$ & $x$ & $\mathrm{x}$ & & $\begin{array}{l}x \\
x\end{array}$ & & & 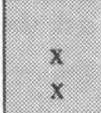 \\
\hline $\begin{array}{l}\text { Resource mobilization } \\
\text { Budget policy } \\
\text { Interest rate policy }\end{array}$ & $x$ & $\begin{array}{l}x \\
x\end{array}$ & $\begin{array}{l}x \\
x\end{array}$ & $\begin{array}{l}\mathrm{x} \\
\mathrm{x}\end{array}$ & & & & $\begin{array}{l}x \\
x\end{array}$ \\
\hline $\begin{array}{l}\text { Debt management } \\
\text { Strengthening of institutional } \\
\text { capacity to manage external } \\
\text { borrowing }\end{array}$ & & $x$ & $\mathrm{x}$ & $\mathrm{x}$ & $x$ & & $\mathrm{x}$ & x \\
\hline
\end{tabular}

I Includes two structural adjustment loans to Turkey.

Source: Landell-Mills, 1981:19. 
six per cent of the total World Bank and IDA lending programme [Landell-Mills 1981:18]. Structural adjustment programmes were agreed with eight countries, of which four were from SSA (Senegal, Kenya, Mauritius and Malawi).

Although the volume of resources devoted to these programmes is still rather limited, the extent to which comprehensive conditionality is involved is already becoming clear. Table 1 provides the World Bank's own assessment of the key components of the programmes with the first eight countries. Unfortunately, while this is a useful illustration, it does not permit a full appreciation of the influence of Bank and Fund policies upon the countries concerned. First, some important measures (especially exchange rate changes) are likely to feature explicitly only in Fund programmes even if they are part of the policy change package called for by the Bank. Second, other measures may have been taken that were not explicit conditions, but which were clearly favoured by the international financial institutions. The World Bank is extremely unlikely to conclude a structural adjustment loan with a country that is not carrying out an IMF stabilisation programme.

\section{Recipient Responses}

If this type of lending by the Bank and the Fund is to grow, and if bilateral donors come to favour an extension of Bank designed and orchestrated conditionality to the disbursement of their own funds, two questions need to be asked. First, must the new types of lending necessarily bring with them a programme of the type advocated in the Report? Second, how can the sub-Saharan countries respond?

As the other articles in this Bulletin suggest, the Report's diagnoses and prescription can be contested from a number of different angles. It is necessary to ask the following questions:

1. Is a largely uniform approach to domestic policy appropriate across the whole range of countries in SSA?

2. Is a sharp move to export-orientation justifiable or even practicable in current and expected international economic conditions?

3. Has the role of the price mechanism been overrated, and the importance of other structural reforms in boosting production been underplayed?

4. Why have questions of income distribution suddenly become unimportant, not only from a welfare point of view, but also in their relationship to the structure of production?
The Report undoubtedly raises a set of issues which are of immense importance given the current economic difficulties of SSA. It is one thing, however, for the Report to be taken as a discussion document, but quite another if (as the Report itself implies) its prescriptions form the core of structural adjustment programmes which the international financial institutions will support. Unless some of the questions it raises are vigorously and critically addressed, at the international level and when country programmes are under consideration, structural adjustment lending could come to be viewed as the vehicle whereby yet another comprehensive and inappropriate policy approach invented by development economists is implemented. In this case the policy approach is one with a strong ideological flavour, with potentially serious political and social costs. The concept of structural adjustment lending involves necessary and overdue reforms in development assistance practices. It can, however, be made compatible with more than one set of policy reforms.

The directions outlined in the Report place very different responsibilities upon the financial and economic policy administrations of African countries in negotiating programme aid from those previously involved in managing a multiplicity of project aid components. The more that Bank and Fund adjustment lending expands, the more recipient governments will find themselves negotiating the framework and components of domestic economic policy with two cooperating outside agencies, instead of negotiating the composition of their development expenditure programmes with a broad range of sources. Inability to reach agreement could have damaging effects, so too could agreement on a programme locally deemed to be misguided. This dilemma was explicitly faced in Tanzania in 1981, where it led to the appointment of what is in effect an arbitration panel - popularly known as the 'Three Wise Men' - to recommend a compromise course between the proposals of the World Bank and the government. ${ }^{6}$ In the long term, arbitration panels are unlikely to be a satisfactory means of determining economic policies. Governments themselves have to face the challenge of mounting their own responses, for their own cases, to programmes such as those proposed by the Report. This task is in some ways comparable to that which has been addressed over the past 20 years or more of evolving more satisfactory bargains with transnational corporations, but there is potentially much more at stake. If the Report stimulates a range of governments to take up the challenge, it will have achieved a great deal.

\footnotetext{
'Their report in April 1982 has to be a substantial extent been embodied in the 1982-83 Budget and Annual Plan. The Bank and Fund response remains unclear.
} 


\section{References}

Acharya, S. N. and B. Johnston, 1978, 'Two studies of development in sub-Saharan Africa', World Bank Staff Working Paper no 300

Balassa, Bela, 1981, 'The policy experience of twelve lessdeveloped countries, 1973-79', World Bank Staff Working Paper no 449

Balassa, Bela et al, 1982, Development Strategies in Semiindustrial Countries, Johns Hopkins University Press for the World Bank

Daniel, Philip, 1981, 'The new recycling: economic theory, IMF conditionality and balance of payments adjustment in the 1980s', Bulletin vol 13 no 1, IDS, Sussex
Krueger, A. O., 1978, Foreign Trade Regimes and Economic Development: Liberalisation Attempts and Consequences, National Bureau of Economic Research, Ballinger, Cambridge, Mass.

Landell-Mills, P. M., 1981, 'Structural adjustment lending: early experience', Finance and Development, vol 18 no 4, December

Liebenthal, R., 1981, 'Adjustment in low-income Africa', World Bank Staff Working Paper no 486

World Bank, $1981 \mathrm{a}$, Accelerated Development in sub-Saharan Africa: an Agenda for Action

-1981b, World Development Report 1981: National and International Adjustment 